Printed ISSN : $2406-7415$

Electronic ISSN : 2655 - 9919

DOI: http://dx.doi.org/10.35137/jabk.v8i3.598

JURNAL AKUNTANSI DAN BISNIS KRISNADWIPAYANA

Volume 8 Nomor 3 (September - Desember) 2021

\title{
ANALISIS PERBANDINGAN KINERJA ANTARA PORTOFOLIO OPTIMAL MODEL MARKOWITZ DAN MODEL INDEKS TUNGGAL (COMPARATIVE ANALYSIS OF PERFORMANCE BETWEEN OPTIMAL PORTOFOLIO MARKOWTIZ MODEL AND SINGLE INDEX MODEL)
}

\author{
Penulis \\ Laurimba Simorangkir \\ Fakultas Ekonomi Universitas Krisnadwipayana \\ Jalan Unkris Jatiwaringin Jakarta Timur \\ Handphone Penulis: 081213818208, email: laurimbasimorangkir@gmail.com
}

\begin{abstract}
The purpose of this study is to determine the composition of stocks, the amount of funding proportion, and optimal portfolio performance formed using Markowitz Model and Single Index Model and to determine whether there are differences in optimal portfolio performance established using Markowitz model and Single Index model based on real simulation or test based statistics. The population in this study is the stock of LQ-45 Group in Indonesia Stock Exchange with the number of selected samples of 30 stocks. Sampling is done by using purposive sampling method. This type of research is simulation and verifikatif (hypothesis testing). The data used are secondary data in the form of monthly stock price data from 2016 to 2019. The analysis technique used is descriptive with the application of portfolio analysis using Markowitz. Model and Single Index Model. Hypothesis testing was done by using independent sample t-test. Based on the results of analysis on the real simulation of optimal portfolio performance formation found that the composition of stocks and the proportion of funds formed optimally there is a difference between the Markowitz Model and the Single Index Model, the optimal portfolio yield rate using the Markowitz Model is higher than the optimal portfolio yield using the Index Model Single, and optimal portfolio risk levels using the Markowitz model is higher than the optimal portfolio risk level using the Single Index Model. But statistically the test of optimal portfolio performance formed using Markowitz. Model and Single Index Model is not significantly different.
\end{abstract}

Keywords: Efficient Portfolio, Optimal Portfolio, Markowitz, Model, Single Index Model, and Sharpe Measure.

\section{PENDAHULUAN}

Pasar modal menyediakan sarana dan fasilitas untuk memungkinkan para investor memperjual-belikan aktiva keuangannya melalui mekanisme yang ada di pasar modal tersebut. Jual-beli aktiva keuangan ini merupakan salah satu kegiatan investasi yang dapat dilakukan di pasar modal oleh investor.

Menurut Reilly dan Brown (2012) suatu investasi adalah komitmen saat ini atas sejumlah dana yang diberikan selama suatu periode waktu yang diminta untuk

Copyright (c) 2021 Laurimba Simorangkir

mendapatkan pembayaran di masa yang akan datang yang akan menjadi kompensasi bagi investor atas (1) periode waktu pendanaan yang dijanjikan, (2) tingkat inflasi yang diharapkan selama periode waktu tersebut, dan (3) ketidakpastian pembayaran di masa depan. Dari definisi investasi tersebut terdapat dua variabel penting dalam investasi. Pertama adalah tingkat imbal hasil yang diharapkan sebagai kompensasi terhadap periode waktu pendanaan dan tingkat inflasi yang terjadi selama periode pendanaan tersebut. Kedua adalah risiko

This work is licensed under a Creative Commons Attribution-NonCommercial-ShareAlike 4.0 International License. 
yaitu ketidakpastian pembayaran yang diterima oleh investor di masa depan. Investasi akan selalu berkaitan dengan imbal hasil dan risiko. Tidak ada investasi tanpa imbal hasil dan risiko, maka keseimbangan antara imbal hasil dan risiko menjadi pertimbangan utama dalam berinvestasi. Salah satu investasi yang menarik perhatian banyak investor adalah investasi pada pasar modal, yaitu investasi saham.

Tujuan para investor berinvestasi dengan memanfaat kan fasilitas pasar modal adalah untuk mendapatkan imbal hasil yang diharapkan tetapi investasi juga mengandung risiko sehingga risiko tersebut harus diminimalisir. Untuk itulah maka investor melakukan diversifikasi yaitu dengan cara mengkombinasikan berbagai sekuritas dalam investasi yang dilakukan. Dalam hal ini para investor membutuhkan pembentukan portofolio. Melalui pembentukan portofolio ini investor dapat memaksimalkan imbal hasil yang diharapkan dari investasi yang dilakukannya dengan tingkat risiko tertentu atau berusaha meminimalkan risiko untuk mencapai tingkat keuntungan tertentu. Inilah yang disebut portofolio efisien. Sehingga dapat dinyatakan bahwa indikator portofolio yang efisien adalah (1) mampu memberikan imbal hasil yang terbesar dengan risiko yang sama, dan (2) mampu memberikan risiko terkecil dengan imbal hasil yang sama (Hartono 2013).

Model Markowitz dan Model Indeks Tunggal dalam pembentukan portofolio mempertimbangkan dan memperhitungkan variabel-variabel yang disebut dengan masukan atau bahan baku dalam pembentukan portofolio dilakukan dengan cermat dan sistematis. Dua model ini menggunakankan bahan baku yang sama tetapi di proses dengan cara yang berbeda sampai menghasilkan portofolio yang optimal. Sehingga kemudian analisis portofolio modern menggunakan dua model ini dalam pembentukan portofolio.

Kinerja portofolio dari kedua model tersebut memungkin berbeda. Perbedaan kinerja portofolio ini akan mempengaruhi para investor untuk memilih model tersebut hingga investor akan lebih cenderung menggunakan salah satu model dari dua model tersebut. Menarik untuk menganalisis bagaimana perbedaan kinerja portofolio yang dihasilkan oleh dua model yang berbeda dan hal-hal apa saja yang membuat kinerja portofolio dua model tersebut berbeda. Sehingga dapat memilih model mana yang memberikan tingkat imbal hasil yang lebih tinggi dan model mana yang lebih praktis atau sederhana digunakan.

Adapun tujuan dan manfaat dari penelitian ini adalah sebagai berikut:

1) Secara teoritis untuk memberikan bukti empiris tentang perbandingan kinerja portofolio optimal yang dibentuk dengan menggunakan model Markowitz dan model Indeks Tunggal.

2) Secara praktek digunakan sebagai acuan dalam pembentukan portofolio optimal oleh investor, perusahaan investasi, pengelola dana pensiun, dan perusahaan asuransi.

3) Hasil penelitian ini diharapkan dapat dijadikan sebagai bahan referensi bagi peneliti lain yang ingin meneliti dan mengembangkan kajian tentang analisis portofolio optimal. 


\section{KAJIAN TEORI}

\section{Teori Investasi}

Pengertian investasi adalah pengorbanan sejumlah uang pada satu atau lebih aset untuk mengharapkan hasil di masa yang datang (Reilly dan Brown, 2012). Sedangkan Jones (2010) mengemukakan investasi merupakan suatu komitmen sejumlah dana pada satu atau aset yang ditahan selama periode waktu tertentu. Jadi investasi merupakan suatu komitmen pengorbanan sejumlah uang saat ini pada satu atau lebih aset untuk mengharapkan hasil di masa yang datang.

Tujuan investasi adalah untuk mengharapkan hasil di masa yang akan datang, di mana hasil tersebut sebagai kompensasi atas kesediaan seseorang (investor) untuk memenuhi kebutuhannya saat dan kemungkinan penurunan nilai investasi (Hartono 2013). Adanya perbedaan waktu antara pengorbanan uang dengan hasil investasi yang akan diterima oleh investor sehingga terdapat kemungkinan hasil yang diterima tidak sesuai dengan hasil yang diharapkan.

Hasil invetasi yang diberikan oleh setiap jenis alternatif investasi yang dipengaruhi oleh banyak faktor. Selain faktor instrumen yang bersangkutan yang biasa disebut faktor fundamental mempengaruhi hasil investasi, faktor eksternal yang biasa disebut dengan faktor teknikal juga mempengaruhi hasil suatu alternatif investasi (Jones 2010). Setap investor mutlak untuk mempertimbangkan dan memonitor setiap faktor yang mempengaruhi hasil investasi agar hasil yang diterima sesuai dengan hasil yang diharapkan.
Volume 8 Nomor 3 (September - Desember) 2021

Adanya kemungkinan hasil yang diterima tidak sesuai dengan hasil yang diharapkan, maka setiap investasi mengandung risiko sehingga risiko investasi tersebut mutlak dikelola agar hasil yang diterima sesuai dengan hasil yang diharapkan. Salah satu cara pengolaan risiko investasi adalah dengan melakukan diversifikasi investasi (Hartono 2013), yaitu investasi dilakukan tidak hanya pada satu jenis investasi tetapi pada beberapa jenis. Hala ini didasarkan pada asumsi bahwa jika terjadi penurunan nilai pada jenis investasi tertentu, terdapat kemungkinan nilai investasi pada jenis investasi lain naik sehingga hasil yang diterima masih sesuai dengan hasil diharapkan. Kumpulan beberapa alternatif investasi biasa disebut dengan portofolio.

\section{Teori Portofolio}

Teori portofolio merupakan teori yang dijelaskan oleh Markowitz (1952), di mana Markowitz dapat memformulasikan secara ilmiah tentang risiko investasi. Teori portofolio yang dikemukakan oleh Markowitz dikenal dengan teori portofolio modern yang dikenal dengan nama "MeanVariance Model".

Portofolio merupakan kumpulan dari beberapa alternatif investasi (Elton et. al. (2014). Portofolio dapat diartikan juga sebagai strategi investasi. Oleh karena investasi merupakan trade-off antara imbal hasil dan risiko investasi (Reilly dan Brown 2012), maka tujuan pembentukan portofolio adalah untuk memaksimalkan hasil dan meminimalisir risiko.

Reilly dan Brown (2012) menyatakan satu asumsi yang mendasar dari teori portofolio adalah bahwa investor ingin 
memaksimumkan imbal hasil dari sekumpulan investasi yang memiliki tingkatan risiko. Artinya bahwa portofolio merupakan kumpulan aset investasi yang masing-masing aset tersebut memiliki tingkatan imbal hasil dan risiko yang berbeda-beda. Karena pada dasar investor tidak menyukai resiko maka mereka akan melakukan proses penyeleksian aset-aset mana yang memiliki tingkat risiko yang rendah.

Dalam teori portofolio modern yang dikemukan oleh Markowitz (1952) terdapat beberapa asumsi yang harus dipenuhi agar tujuan pembentukan tercapai. Salah satu asumsi teori portofolio modern adalah pemilihan alternatif investasi didasarkan pada mean (rata-rata) dari imbal hasil dari alternatif investasi yang biasa disebut dengan imbal hasil yang diharapkan (expected return) yang terbesar dan variance (varians) dari alternatif investasi yang ukuran penyimpangan atau risiko yang terkecil.

Oleh karena investasi bersifat "high risk, high return". Artinya alternatif investasi yang memberikan imbal hasil tinggi, maka alternatif investasi tersebut memiliki risiko yang tinggi. Sehingga dalam pemilihan alternatif investasi yang masuk ke dalam portofolio harus mempertimbangkan bagaimana hubungan antar alternatif investasi yang tercermin pada nilai kovarians atau koefisien korelasi antar alternatif investasi.

\section{Portofolio Model Markowitz}

Pertimbangan utama dalam berinvestasi adalah imbal hasil dan risiko. Prinsip pembentukan portofolio dengan model Markowitz mendasari analisisnya pada mean dan variance. Dimana mean(rata-rata) merupakan pengukuran tingkat imbal hasil sedangkan variancemerupakan pengukuran tingkat risiko. Maka pembentukan portofolio model Markowitz dapat juga dikatakan pembentukan portofolio dengan analisis imbal hasil dan risiko. Dalam sejarah pembentukan portofolio model Markowitz merupakan model pertama yang memprediksi imbal hasil yang diperoleh berdasarkan harga sekuritas dengan menggunakan parameter-parameter input berupa imbal hasil yang diharapkan dan varian dari masing-masing sekuritas serta kovarian antar 2 (dua) sekuritas di dalam portofolio yang semuanya diprediksi berdasarkan harga sekuritas.Perhitunganperhitungan yang dilakukan untuk mendapatkan portofolio optimal hanya ditentukan oleh 3 (tiga) variabel tersebut (Imbal hasil yang diharapkan, varian, dan kovarian). Tetapi dalam analisisnya diperlukan analisis korelasi antar imbal hasil yang diharapkan dari masing-masing sekuritas.

Dalam pembentukan portofolio model Markowitz ini perlu dipahami asumsi-asumsi yang digunakan yaitu waktu yang digunakan hanya satu periode, tidak ada biaya transaksi, preferensi investor hanya didasarkan pada imbal hasil yang diharapkan dan risiko dari portofolio, dan tidak ada pinjaman dan simpanan bebas risiko.

\section{Portofolio Model Indeks Tunggal}

Model Markowitz yang telah dijelaskan sebelumnya merupakan metode pertama dalam pembentukan portofolio dengan melakukan analisis imbal hasil dan risiko 
secara detail dan cermat. Dan kemudian muncul model lain dalam pembentukan portofolio merupakan pengembangan dari model Markowitz. Di mana model-model yang lahir kemudian melakukan pengembangan implementasi pembentukan portofolio dalam dua ketegori yaitu: yang pertama mengambil perhatian pada penyederhanaan jumlah dan tipe dari data input dalam melakukan analisis portofolio dan yang kedua melakukan penyederhanaan dalam prosedur perhitungan yang dibutuhkan dalam menghitung portofolio yang optimal. Satu yang tertua dan paling luas melakukan penyederhanaan terhadap struktur portofolio adalah model indeks tunggal (the singleindex model) (Elton et al, 2014).

William Sharpe mengembangkan model yang disebut dengan single index model. Model ini merupakan penyederhanaan perhitungan model Markowitz dengan menyediakan parameter-parameter input yang dibutuhkan di dalam perhitungan model Markowitz. Dimana dalam model markowitz dirasakan sangat kompleks dalam mengestimasi imbal hasil dan risiko dari setiap saham individu yang masuk pada portofolio terutama dalam mengestimasi koefisien korelasi antar dua saham yang dipasangkan dalam portofolio. Ternyata model indeks tunggal bukan saja terkait estimasi matrik korelasi tetapi juga dalam menguji pasar efisien dan keseimbangan (Elton et al, 2014).

Dalam melakukan estimasi terhadap variabel-variabel input model indeks tunggal menggunakan sumsi-asumsi sebagai berikut (Hartono, 2013):

(a) Kesalahan residu dari sekuritas ke-i tidak berkovari (berkorelasi) dengan kesalahan residu sekuritas ke-j atau $e_{i}$ tidak berkorelasi dengan $\mathrm{e}_{\mathrm{j}}$ untuk semua nilai dari i dan $\mathrm{j}$.

(b) Return indek pasar $\left(\mathrm{R}_{\mathrm{M}}\right)$ dan kesalahan residu untuk tiap-tiap sekuritas $\left(\mathrm{e}_{\mathrm{i}}\right)$ merupakan variabel-variabel acak sehingga diasumsikan bahwa $\mathrm{e}_{\mathrm{i}}$ tidak berkovari dengan return indeks pasar.

\section{METODE PENELITIAN}

Penelitian ini menggunakan metode eksperimen dan eksplanasi. Metode eksperimen adalah metode penelitian dengan melakukan simulasi atau perlakuan atas objek yang diteliti. Metode simulasi yang dilakukan dengan cara membentuk portofolio saham pada awal tahun dan menghitung kinerja portofolio yang dibentuk pada akhir tahun untuk masing-masing model. Sedangkan metode eksplanasi adalah melakukan deskripsi dan pengujian atas variabel yang diteliti.

Penelitian ini menggunakan data sekunder berupa data harga saham perusahaan yang tercatat di Bursa Efek Indonesia (BEI), indeks harga saham, dan tingkat suku bunga. Data harga saham yang digunakan adalah harga saham penutupan akhir perusahaan yang masuk dalam indeks LQ-45 dan untuk menentukan kandidat saham yang masuk ke dalam portofolio dilakukan seleksi dengan membandingkan imbal hasil yang diharapkan dari masingmasing saham dengan imbal hasil pasar. Jika imbal hasil yang diharapkan dari masingmasing saham lebih besar dari imbal hasil pasar, maka saham yang bersangkutan menjadi kandidat yang dipilih masuk ke dalam portofolio. 
Dari kandidat saham yang terseleksi masuk ke masing-masing jenis portofolio, selanjutnya dibentuk portofolio yang optimal. Kemudian dilakukan evaluasi kinerja portofolio optimal yang terbentuk dari masing-masing model. Indikator kinerja portofolio yang dianalisis antara lain (1) imbal hasil portofolio yang diharapkan (expected reteurn of portfolio), (2) risiko portofolio, dan (3) menggunakan indikator tertentu seperti koefisien variasi $(\mathrm{CV}=$ Coefficient Variation, yaitu membandingkan risiko dengan imbal hasil yang diharapkan), dan Ukuran Sharpe (membandingkan imbal hasil yang diharapkan dengan risiko). Selanjutnya dilakukan pengujian hipotesis untuk mengetahui apakah terdapat perbedaan kinerja portofolio yang dibentuk menggunakan model Markowitz dan Indeks Tunggal. Pengujian hipotesis dilakukan dengan metode statistik uji beda.

\section{Pembentukan Portofolio Optimal}

1) Portofolio Model Markowitz atau Mean Variance Model (MVM)

Langkah-langkah pembentukan portofolio menggunakan model Markowitz adalah sebagai berikut:

a) Mengestimasi atau menghitung variabel yang diperlukan dalam pembentukan portfolio model Markowitz, yaitu:.

(1) Imbal hasil aktual dan imbal hasil yang diharapkan dari masing-masing masing-masing akan dipilih masuk ke dalam portofolio.

(2) Varians dan standar deviasi dari masing-masing saham yang akan dipilih masuk ke dalam portofolio.

(3) Kovarians dan koefisien korelasi antar-saham.

b) Menentukan kandidat saham yang masuk ke dalam portofolio.

Kandidat saham yang masuk ke dalam portfolio adalah sahamsaham yang memiliki imbal hasil yang diharapkan yang positif dan nilainya lebih besar dari imbal hasil pasar yang diharapkan. Oleh karena penelitian ini menggunakan metode simulasi, maka akan dibentuk 3 (tiga) portofolio, yaitu:

Portofolio I, yaitu portofolio yang dibentuk berdasarkan data 2016.

Portofolio II, yaitu portofolio yang dibentuk berdasarkan data 2017.

Portofolio III, yaitu portofolio yang dibentuk berdasarkan data 2018.

c) Menentukan portofolio yang Optimal.

Portofolio optimal yang akan dibentuk terdiri dari kandidat saham yang terpilih. Portofolio optimal yang akan dibentuk menggunakan pendekatan GMV (Global Minimum Variance), yaitu portofolio yang memiliki risiko (variance) paling rendah (minimum). Oleh karena tujuan pembentukan portofolio adalah risiko minimal, maka untuk menentukan portofolio efisien menggunakan model optimalisasi (Quadratic Programming) dengan fungsi tujuan minimalisasi risiko (variance) dengan cara sebagai berikut: 
Printed ISSN : $2406-7415$

Electronic ISSN : 2655 - 9919

DOI: http://dx.doi.org/10.35137/jabk.v8i3.598

Fungsi tujuan:

$$
\frac{\text { Minimalkan }}{\operatorname{Var} E\left(R_{p}\right)}=\sum_{i=1}^{N} X_{i} . \sigma_{i}^{2}+\sum_{i=1}^{N} \sum_{\substack{j=1 \\ i \neq j}}^{N} X_{i} X_{j} \sigma_{i, j}
$$

Fungsi kendala:

$$
\sum_{i=1}^{n} W_{i}=1
$$

dan

$\mathrm{W}_{\mathrm{i}} \geq 0$ untuk $\mathrm{i}=1$ sampai dengan $\mathrm{n}$ Untuk memperoleh nilai optimal alokasi dana pada masing-masing saham, model di atas diselesaikan dengan menggunakan persamaan simultan (simplex) atau menggunakan bantuan program computer MS Excel Solver.

d) Menghitung imbal hasil portofolio yang diharapkan (expected portfolio return) dan risiko portfolio dengan menggunakan formula yang diuraikan pada operasionalisasi variabel di atas.

e) Menghitung imbal hasil portofolio riil dan besarnya risiko untuk 1 (satu) periode yaitu 1 tahun dengan cara mengalikan alokasi dana dengan harga penutupan akhir periode dari masing-masing saham yang masuk ke dalam portofolio yang terbentuk.

f) Evaluasi kinerja portfolio dengan menggunakan indikator koefisien variasi dan ukuran sharpe.

2) Portofolio Model Indeks Tunggal (Single Index Model)

Langkah-langkah pembentukan portofolio menggunakan model indeks tungal (Single Index Model = SIM) sebagai berikut:
JURNAL AKUNTANSI DAN BISNIS KRISNADWIPAYANA

Volume 8 Nomor 3 (September - Desember) 2021 a) Mengestimasi atau menghitung variabel yang diperlukan dalam pembentukan portfolio model indeks tunggal, yaitu:.

(1) Beta dan alpha dari masingmasing saham yang memenuhi kriteria yaitu mempunyai imbal hasil yang diharapkan positif dan lebih besar dari imbal hasil pasar yang diharapkan dengan menggunakan formula yang diuraikan pada subbab di atas.

(2) Beta dan alpha portofolio dengan menggunakan formula yang diuraikan pada subbab di atas.

(3) Imbal hasil aktual dan yang diharapkan dari pasar dengan menggunakan formula yang diuraikan pada subbab di atas.

b) Menentukan portofolio yang optimal. Penentuan portofolio efisien menggunaan model indeks tunggal dilakukan sebagai berikut:

(1) Menentukan rasio antara ekses return dengan beta (excess return to beta ratio):

$$
E R B_{i}=\frac{E\left(R_{i}\right)-R_{B R}}{\beta_{i}}
$$

Mengurutkan saham dari ERB tertinggi ke ERB terendah.

(2) Menghitung nilai $A_{i}$ dan $B_{i}$ untuk masing-masing sekuritas ke-i sebagai berikut:

dan

$$
A_{i}=\frac{\left[E\left(R_{i}\right)-R_{B R}\right] \cdot \beta_{i}}{\sigma_{e i}^{2}}
$$

$$
B_{i}=\frac{\beta_{i}^{2}}{\sigma_{e i}^{2}}
$$


(3) Menentukan besarnya cut-off point $\left(\mathrm{C}^{*}\right)$ dengan formula sebagai berikut:

$$
C_{i}=\frac{\sigma_{M}^{2} \sum_{j=1}^{i} A_{j}}{1+\sigma_{M}^{2} \sum_{j=1}^{i} B_{j}}
$$

(4) Menentukan proporsi alokasi dana masing-masing saham yang masuk ke dalam portofolio dengan formula sebagai berikut:

$$
W_{i}=\frac{Z_{i}}{\sum_{j=1}^{k} Z_{i}}
$$

dengan nilai $\mathrm{Z}_{\mathrm{i}}$ adalah:

$$
Z_{i}=\frac{\beta_{i}}{\sigma_{e i}^{2}}\left(E R B_{i}-C^{*}\right)
$$

c) Menghitung imbal hasil portofolio yang diharapkan (expected portfolio return) dan risiko portfolio dengan menggunakan formula yang diuraikan pada operasionalisasi variabel di atas.

d) Menghitung imbal hasil portofolio riil dan besarnya risiko untuk 1 (satu) periode yaitu 1 tahun dengan cara mengalikan alokasi dana dengan harga penutupan akhir periode dari masing-masing saham yang masuk ke dalam portofolio yang terbentuk.

e) Evaluasi kinerja portfolio dengan menggunakan indikator koefisien variasi dan ukuran sharpe.
Pengujian hipotesis dilakukan dengan menggunakan independent sampel t-test yaitu untuk menguji signifikansi beda ratarata dua kelompok data dengan bantuan software SPSS version 17. Adapun hipotesis yang akan diuji adalah sebagai berikut:

$\mathrm{H}_{1}$ : Terdapat perbedaan imbal hasil portofolio efisien dengan menggunakan model Markowitz dan model Indeks Tunggal (Single Index Model).

$\mathrm{H}_{2}$ : Terdapat perbedaan tingkat risiko portofolio efisien dengan menggunakan model Markowitz dan model Indeks Tunggal (Single Index Model).

$\mathrm{H}_{3}$ : Terdapat perbedaan indikator kinerja portofolio ukuran Sharpe (Sharpe) dari portofolio efisien dengan menggunakan model Markowitz dan model Indeks Tunggal (Single Index Model).

\section{HASIL PENELITIAN DAN PEMBAHASAN}

\section{Model Markowitz}

\section{Periode 2016.}

Berdasarkan data imbal hasil saham masing-masing saham terdapat 14 (empat belas) emiten menjadi kandidat dan terpilih 6 (enam) emiten. Ke-enam saham yang terpilih yang dibeli pada awal 2016, sehingga terbentuk portofolio periode 2016. Adapun saham yang terpilih dan besarnya alokasi dana pada masing-masing sebagaimana terlihat pada Lampiran 1.

\section{Pengujian Hipotesis}




\section{Periode 2017}

Berdasarkan data imbal hasil masingmasing saham terdapat 17 (tujuh belas) emiten menjadi kandidat dan terpilih 9 (sembilan) emiten. Ke-sembilan saham yang terpilih yang dibeli pada awal 2017, sehingga terbentuk portofolio periode 2017. Adapun saham yang terpilih dan besarnya alokasi dana pada masing-masing sebagaimana terlihat pada Lampiran 1.

\section{Periode 2018}

Berdasarkan data imbal hasil masingmasing saham terdapat 7 (tujuh) emiten menjadi kandidat dan terpilih 5 (tujuh) emiten. Ke-lima saham yang terpilih akan dibeli pada awal 2018, sehingga terbentuk portofolio periode 2018.. Adapun saham yang terpilih dan besarnya alokasi dana pada masing-masing sebagaimana terlihat pada Tabel 1.

\section{Periode 2019}

Berdasarkan data imbal hasil masingmasing saham terdapat 21 (dua puluh satu) emiten menjadi kandidat dan terpilih hanya 7 (tujuh) emiten. Ketujuh saham yang terpilih dibeli pada awal 2019, sehingga terbentuk portofolio periode 2019. Adapun saham yang terpilih dan besarnya alokasi dana pada masing-masing sebagaimana terlihat pada Lampiran 1.

\section{Model Indeks Tunggal}

\section{Periode 2016}

Berdasarkan data imbal hasil masingmasing saham terdapat 14 (empat belas) emiten menjadi kandidat dan terpilih hanya 3 (tiga) emiten. Ketiga saham yang terpilih dibeli pada awal 2016, sehingga terbentuk portofolio periode 2016. Adapun saham yang terpilih dan besarnya alokasi pada masingmasing sebagaimana terlihat pada Lampiran1

\section{Periode 2017}

Berdasarkan data imbal hasil masingmasing saham terdapat 17 (tujuh belas) emiten menjadi kandidat dan terpilih hanya 16 (enam belas) emiten. Keenambelas saham yang terpilih dibeli pada awal 2014, sehingga terbentuk portofolio periode 2015. Adapun saham yang terpilih dan besarnya alokasi pada masing-masing sebagaimana terlihat pada Lampiran 1.

\section{Periode 2018}

Berdasarkan data imbal hasil masingmasing saham terdapat 7 (tujuh) emiten menjadi kandidat dan terpilih 6 (enam) emiten. Ke-enam saham yang terpilih dibeli pada awal 2018, sehingga terbentuk portofolio periode 2018. Adapun saham yang terpilih dan besarnya alokasi pada masingmasing sebagaimana terlihat pada Lampiran1

\section{Periode 2019}

Berdasarkan data imbal hasil masingmasing saham terdapat 21 (dua puluh satu) emiten menjadi kandidat dan terpilih 18 (delapan belas) emiten. Kedelapanbelas saham yang terpilih dibeli pada awal 2018, sehingga terbentuk portofolio periode 2018 . Adapun saham yang terpilih dan besarnya alokasi pada masing-masing sebagaimana terlihat pada Lampiran 1.

\section{Imbal Hasil dan Risiko Portofolio Optimal}

\section{Model Markowitz}


Hasil komputasi portofolio optimal Model Markowitz seperti terlihat pada pada Lampiran 2 dapat diuraikan sebagai berikut:

1) Jumlah saham yang terpilih dari kandidat saham yang tersedia untuk setiap portofolio yang terbentuk tidak sama. Portofolio optimal periode 2017 memiliki jumlah saham terbanyak yaitu 9 (sembilan) saham sedangkan portofolio periode 2018 memiliki saham yang tersedikit, yang terbentuk hanya terdiri dari 5 (lima) saham.

2) Portofolio optimal yang memiliki imbal hasil yang diharapkan terbesar adalah portofolio periode 2017 sebesar 28,39\% pertahun dan portofolio optimal terkecil adalah portofolio periode 2016 sebesar $14,80 \%$ pertahun.

3) Portofolio optimal yang memiliki risiko terbesar adalah portofolio periode 2019 sebesar 5,32\% pertahun dan portofolio optimal yang mempunyai risiko terkecil adalah portofolio periode 2017 sebesar $1,78 \%$ pertahun.

4) Jumlah saham yang terpilih masuk ke dalam portofolio optimal mempunyai korelasi negatif dengan risiko. Semakin banyak saham yang masuk ke dalam portofolio, risiko semakin rendah. Hal ini sejalan dengan tujuan pembentukan portofolio yaitu meminimalisasi risiko melalui portofolio. Portofolio optimal mempunyai tingkat risiko yang lebih kecil dibandingkan tingkat risiko saham secara individual.

\section{Model Indeks Tunggal}

Hasil komputasi portofolio optimal Model Indeks Tungga seperti terlihat pada Lampiran 3 dapat diuraikan sebagai berikut:
1) Jumlah saham yang terpilih dari kandidat saham yang tersedia untuk setiap portofolio yang terbentuk tidak sama. Portofolio optimal periode 2019 memiliki jumlah saham terbanyak yaitu 18 (delapan belas) saham sedangkan portofolio periode 2016 yang terbentuk hanya terdiri dari 3 saham.

2) Portofolio optimal yang memiliki imbal hasil yang diharapkan terbesar adalah portofolio periode 2018 sebesar 32,18\% pertahun dan portofolio optimal terkecil adalah portofolio periode 2019 sebesar $13,82 \%$ pertahun.

3) Portofolio optimal yang memiliki risiko terbesar adalah portofolio periode 2018 sebesar $6,05 \%$ pertahun dan portofolio optimal yang mempunyai risiko terkecil adalah portofolio periode 2017 sebesar $0,46 \%$ pertahun.

4) Jumlah saham yang terpilih masuk ke dalam portofolio optimal mempunyai korelasi negatif dengan risiko. Semakin banyak saham yang masuk ke dalam portofolio, risiko semakin rendah. Hal ini sejalan dengan tujuan pembentukan portofolio minimalisasi risiko melalui portofolio. Portofolio optimal mempunyai tingkat risiko yang lebih kecil dibandingkan tingkat risiko saham secara individual.

\section{Hasil Uji Statistik}

Dasar pengambilan keputusan uji normalitas berdasarkan Kolmograf Smirnov Test adalah sebagai berikut:

1) Jika signifikasi (2-tailed) $>0.05$, maka Ho diterima dan Ha ditolak.

2) Jika signifikasi (2-tailed) $<0.05$, maka Ho ditolak dan Ha diterima. 
Adapun data kinerja portfolio optimal yang akan diuji sebagaimana terlihat pada Tabel 1.

Tabel 1. Data Uji Beda

\begin{tabular}{|c|c|c|c|c|c|c|}
\hline \multirow{2}{*}{ Periode } & \multicolumn{2}{|c|}{$\begin{array}{c}\text { Imbal Hasil } \\
\text { Portofolio }\end{array}$} & \multicolumn{2}{c|}{ Risiko Portofolio } & \multicolumn{2}{c|}{ Kinerja Sharpe } \\
\cline { 2 - 7 } & MAR & MIT & MAR & MIT & MAR & MIT \\
\hline 2016 & $14,80 \%$ & $14,24 \%$ & $3,95 \%$ & $2,71 \%$ & 0,08 & 0,07 \\
\hline 2017 & $28,39 \%$ & $27,96 \%$ & $1,78 \%$ & $0,46 \%$ & 0,23 & 0,22 \\
\hline 2018 & $23,94 \%$ & $32,18 \%$ & $5,07 \%$ & $6,05 \%$ & 0,19 & 0,27 \\
\hline 2019 & $18,49 \%$ & $13,82 \%$ & $5,32 \%$ & $1,97 \%$ & 0,14 & 0,09 \\
\hline
\end{tabular}

Sumber: Hasil Perhitungan Portofolio Optimal

Dari hasil komputasi data pada Tabel 4 diperoleh parameter uji hipotesis sebagaimana terlihat pada Tabel 2 .

Tabel 2. Parameter Statistik Uji Beda

\begin{tabular}{|l|c|c|c|c|}
\hline \multirow{2}{*}{ Variabel } & \multicolumn{2}{|c|}{ F-hitung } & \multicolumn{2}{c|}{ t-hitung } \\
\cline { 2 - 5 } & Nilai & $\begin{array}{c}\text { Signifi } \\
\text { kansi }\end{array}$ & Nilai & $\begin{array}{c}\text { Sig (2- } \\
\text { taailed) }\end{array}$ \\
\hline Imbal Hasil & 4,98 & 0,067 & $-0,12$ & 0,912 \\
\hline Tingkat Risiko & 0,3 & 0,604 & 0,863 & 0,421 \\
\hline Ukuran Sharpe & 3,46 & 0,011 & 0,11 & 0,916 \\
\hline
\end{tabular}

Sumber:Hasil komputasi dengan SPSS

Berdasarkan Tabel 1 dan Tabel 2 dapat ditarik kesimpulan sebagai berikut:

1) Hipotesis kesatu:

Ho: Tidak terdapat perbedaan imbal hasil portofolio efisien menggunakan model Markowitz dengan model indeks tunggal (Single Index Model).

Ha: Terdapat perbedaan imbal hasil portofolio efisien menggunakan model Markowitz dengan model indeks tunggal (Single Index Model).

Dari Tabel 2 dapat diketahui bahwa nilai thitung sebesar -0,116 dengan sig (2-tailed) sebesar 0,912. Oleh karena nilai sig (2-tailed) $>$ dari 0,05 , maka hipotesis $\mathrm{H}_{\mathrm{o}}$ diterima dan $\mathrm{H}_{\mathrm{a}}$ ditolak. Artinya rata-rata imbal hasil portofolio efisien yang dibentuk menggunakan model Markowitz dengan model Indeks Tunggal (MIT) tidak berbeda nyata.

2) Hipotesis kedua:

Ho: Tidak terdapat perbedaan risiko portofolio efisien menggunakan model Markowitz dengan model Indeks Tunggal (Single Index Model).

Ha: Terdapat perbedaan risiko portofolio efisien menggunakan model Markowitz dengan model Indeks Tunggal (Single Index Model).

Dari Tabel 2 dapat diketahui bahwa nilai thitung sebesar 0,863 dengan sig (2-tailed) sebesar 0,421. Oleh karena nilai sig (2-tailed) $>$ dari 0,05 , maka hipotesis $\mathrm{H}_{\mathrm{o}}$ diterima dan $\mathrm{H}_{\mathrm{a}}$ ditolak. Artinya rata-rata tingkat risiko portofolio efisien yang dibentuk menggunakan model Markowitz dengan Model Indeks Tunggal (MIT) tidak berbeda nyata.

3) Hipotesis ketiga:

Ho: Tidak terdapat perbedaan indikator kinerja portofolio ukuran Sharpe (Sharpe Measure) dari portofolio efisien menggunakan model 
Markowitz dengan model indeks tunggal (Single Index Model).

Ha: Terdapat perbedaan indikator kinerja portofolio ukuran Sharpe (Sharpe Measure) dari portofolio efisien menggunakan model Markowitz dengan model indeks tunggal (Single Index Model).

Dari Tabel 2 dapat diketahui bahwa nilai thitung sebesar 0,110 dengan sig (2-tailed) sebesar 0,916 . Oleh karena nilai sig (2-tailed) $>$ dari 0,05 , maka hipotesis Ho diterima dan Ha ditolak. Artinya rata-rata indikator portofolio ukuran Sharpe (Sharpe Measure) yang dibentuk menggunakan Model Markowitz dengan Model Indeks Tunggal tdiak berbeda nyata.

\section{Pembahasan Hasil Penelitian}

\section{Perbandingan Komposisi Saham dan Proporsi Dana Portofolio Optimal}

Berdasarkan hasil komputasi komposisi saham dan proporsi dana sebagaimana terlihat pada Lampiran 1 dapat diketahui dari 4 (empat) periode yang diobservasi model Indeks Tunggal menghasilkan jumlah saham yang lebih banyak dibanding Model Markowitz. Hal ini menunjukkan bahwa dari jumlah kandidat saham yang sama untuk masuk ke dalam portofolio optimal, Model Indeks Tunggal cenderung membentuk jumlah saham yang lebih banyak menjadi saham portofolio optimal dibanding Model Markowitz.

Di samping itu, berdasarkan hasil komputasi portofolio optimal sebagaimana yang terlihat pada Lampiran 2 dan Lampiran 3 terlihat bahwa semakin banyak jumlah saham yang terbentuk optimal maka semakin kecil tingkat risiko yang terbentuk dalam portofolio optimal tersebut. Hal ini membuktikan teori yang menyatakan dengan menambah jumlah saham dalam portofolio maka risiko portofolio akan makin berkurang tetapi tidak pernah bisa dihilangkan (Husnan 2015).

Sejalan dengan jumlah saham yang dihasilkan maka proporsi dana yang terbentuk dalam portofolio optimal juga berbeda antara Model Markowit dan Model Indeks Tunggal. Hal ini dapat dilihat dengan membandingkan Tabel 1 dan Tabel 2 dengan komposisi saham yang terbentuk optimal berbeda antara Model Markowitz dan Model Indeks Tunggal maka komposisi dana akan mengikuti jumlah saham yang dihasilkan tersebut. Secara faktual ditemukan hasil bahwa jumlah saham dan proporsi dana yang dialokasikan pada masing-masing saham yang terpilih dari kandidat saham yang tersedia tidak sama antara Model Markowitz dan Model Indeks Tunggal.

\section{Perbandingan imbal hasil dan risiko portofolio optimal}

Berdasarkan perbandingan imbal hasil dan risiko portofolio optimal sebagaimana yang terlihat pada Lampiran 4 dapat diketahui bahwa tingkat imbal hasil yang diharapkan dari portofolio optimal Model Markowitz lebih tinggi dibandingkan dengan tingkat imbal hasil yang diharapkan dari portofolio optimal Model Indeks Tunggal. Tetapi perbedaan secara faktual tersebut dalam jumlah yang kecil atau tidak signifikan. Dari 4 (empat) periode yang diobservasi hanya tahun 2018 yang menunjukkan perbedaan tingkat imbal hasil 
yang berbeda signifikan sedangkan 3 (tiga) periode menunjukkan perbedaan yang kecil. Dan terlihat memiliki kecenderungan Model Markowitz memberikan imbal hasil yang lebih tinggi dibanding Model Indeks Tunggal.

Berdasarkan pengujian statistik sebagaimana yang dapat dilihat pada Tabel 2 dapat diketahui bahwa nilai t-hitung sebesar 0,116 dengan sig (2-tailed) sebesar 0,912. Oleh karena nilai sig (2-tailed) > dari 0,05, maka hipotesis $\mathrm{H}_{\mathrm{o}}$ diterima dan $\mathrm{H}_{\mathrm{a}}$ ditolak. Artinya rata-rata imbal hasil portofolio efisien yang dibentuk menggunakan Model Markowitz (MAR) dengan Model Indeks Tunggal (MIT) tidak berbeda nyata. Hasil pengujian statistik ini membuktikan bahwa tingkat imbal hasil yang diharapkan dari portofolio optimal Model Markowitz tidak berbeda nyata bila dibandingkan dengan tingkat imbal hasil yang diharapkan dari portofolio optimal Model Indeks Tunggal.

Di sisi lain, bahwa tingkat risiko dari portofolio optimal yang diukur berdasarkan standar deviasi Model Indeks Tunggal lebih rendah dibandingkan dengan tingkat risiko dari portofolio optimal Model Markowitz. Perbedaan tingkat risiko portofolio optimal ini secara faktual menunjukkan perbedaan yang signifikan.

Tetapi berdasarkan pengujian statistik sebagaimana yang dapat dilihat pada Tabel 2 dapat diketahui bahwa nilai t-hitung sebesar 0,863 dengan sig (2-tailed) sebesar 0,421. Oleh karena nilai sig (2-tailed) $>$ dari 0,05 , maka hipotesis $\mathrm{H}_{\mathrm{o}}$ diterima dan $\mathrm{H}_{\mathrm{a}}$ ditolak. Artinya rata-rata tingkat risiko portofolio optimal yang dibentuk menggunakan Model Markowitz dengan Model Indeks Tunggal (MIT) tidak berbeda nyata. Pengujian statistik ini membuktikan bahwa tingkat risiko yang terbentuk dari portofolio optimal Model Markowitz tidak berbeda nyata bila dibandingkan dengan tingkat risiko yang terbentuk dari portofolio optimal Model Indeks Tunggal.

\section{Perbandingan kinerja portofolio optimal}

Berdasarkan rekapitulasi indikator kinerja portofolio sebagaimana yang terlihat pada Lampiran 5 dapat diketahui kinerja portofolio yang terbentuk sebagai berikut:

a) Indikator CV (Coefficient Variation) Pengambilan keputusan kinerja portofolio menggunakan indikator $\mathrm{CV}$ adalah angka $\mathrm{CV}$ kecil mencerminkan kinerja portofolio yang lebih baik (superior) dibandingkan angka $\mathrm{CV}$ besar. Portofolio efisien yang terbentuk periode 2017 merupakan portofolio terbaik (superior) dengan $\mathrm{CV}$ sebesar 0,405 dan portofolio yang buruk (inferior) menggunakan indikator $\mathrm{CV}$ adalah portfolio yang dibentuk untuk periode 2019 dengan CV sebesar 1,857. CV sebesar 0,405, artinya setiap risiko sebesar 0,405\% dicover oleh imbal hasil sebesar $1 \%$. Sedangkan CV sebesar $1,857 \%$, artinya setiaap risiko $1,857 \%$ hanya dicover oleh imbal hasil sebesar $1 \%$.

Untuk portofolio yang dibentuk menggunakan Model Indeks Tunggal (MIT) diperoleh portofolio yang terbentuk periode 2017 merupakan portofolio terbaik (superior) karena memiliki CV terkecil sebesar 0,107 sedangkan portofolio yang terbentuk periode 2016 merupakan portofolio yang buruk (inferior) karena memiliki CV terbesar sebesar 1,218. 
b) Indikator Ukuran Sharpe (Sharpe Measure)

Pengambilan keputusan kinerja portofolio menggunakan indikator ukuran Sharpe (Sharpe Measure) adalah angka Sharpe tinggi mencerminkan kinerja portofolio yang lebih baik (superior) dibandingkan angka Sharpe rendah. Portofolio optimal yang terbentuk periode 2017 merupakan portofolio terbaik (superior) dengan ukuran Sharpe sebesar 1,885 dan portofolio yang buruk (inferior) menggunakan indikator $\mathrm{CV}$ adalah portfolio yang dibentuk untuk periode 2016 dengan CV sebesar 0,316. Angak Sharpe sebesar 1,885, artinya setiap imbal hasil sebesar $1,885 \%$ mempunyai risiko sebesar $1 \%$. Sedangkan angka Sharpe sebesar $0,316 \%$, artinya setiap $0,316 \%$ imbal hasil memiliki risiko sebesar $1 \%$.

Untuk portofolio yang dibentuk menggunakan Model Indeks Tunggal (MIT) diperoleh portofolio yang terbentuk periode 2017 merupakan portofolio terbaik (superior) karena memiliki ukuran Sharpe terbesar sebesar 7,080 sedangkan portofolio yang terbentuk periode 2016 merupakan portofolio yang buruk (inferior) karena memiliki CV terbesar sebesar 1,218.

Berdasarkan perhitungan kinerja portfolio aktual sebagaimana terlihat pada Lampiran 6 dapat diketahui kinerja portofolio yang terbentuk untuk masing-masing model sebagai berikut:

1) Kinerja Portofolio Model Markowitz Dari Tabel 8 dapat diketahui bahwa kinerja portofolio terbaik adalah portofolio periode 2016. Nilai awal investasi saham yang masuk ke dalam portofolio $2016 \quad$ sebesar Rp999.747.000,- dan pada akhir periode 2016 naik menjadi sebesar Rp1.110.601.000,- atau naik sebesar Rp.110.854.000,- atau portofolio periode 2016 mampu memberikan imbal hasil sebesar $11,09 \%$ selama 1 (satu) periode. Sedangkan kinerja portofolio terburuk adalah portofolio periode 2017 . Nilai awal investasi saham yang masuk ke dalam portofolio 2017 sebesar Rp999.966.000,- dan pada akhir periode 2017 turun menjadi sebesar Rp686.980.500,- atau turun sebesar Rp.312.985.500,- atau portofolio periode 2017 memberikan imbal hasil negatif sebesar $31,30 \%$ selama 1 (satu) periode.

2) Kinerja Portofolio Model Indeks Tunggal

Dari Tabel 8 dapat diketahui bahwa kinerja portofolio terbaik adalah portofolio periode 2016. Nilai awal investasi saham yang masuk ke dalam portofolio 2016 sebesar $\mathrm{Rp}$ 997.572.500,- dan pada akhir periode 2016 naik menjadi sebesar Rp1.321.885.500,- atau naik sebesar Rp324.313..000,- atau portofolio periode 2016 mampu memberikan imbal hasil sebesar $32,51 \%$ selama 1 (satu) periode. Sedangkan kinerja portofolio terburuk adalah portofolio periode 2017. Nilai awal investasi saham yang masuk ke dalam portofolio 2017 sebesar Rp996.971.500,- dan pada akhir periode 2017 turun menjadi sebesar Rp820.764.200,- atau turun sebesar Rp.176.207.300,- atau portofolio 
periode 2017 memberikan imbal hasil negatif sebesar $17,67 \%$ selama 1 (satu) periode.

Evaluasi kinerja portofolio yang dibandingkan dalam penelitian ini dilakukan pada saat pra-pembentukan portofolio yaitu dengan menggunakan indikator ukuran sharpe dan pada saat pasca-pembentukan portofolio yaitu dengan melakukan simulasi investasi riil berdasarkan portofolio optimal yang terbentuk.

Dari Lampiran 5 dapat dilihat bahwa berdasarkan evaluasi kinerja portofolio dengan menggunakan indikator ukuran sharpe (Sharpe Measure) kinerja portofolio yang hasilkan oleh Model Indeks Tunggal secara faktual lebih tinggi dari kinerja yang dihasilkan oleh Model Markowitz. Dari 4 (empat) periode yang diamati semua periode menunjukkan kinerja Model Indeks Tunggal secara siginfikan lebih tinggi dari kinerja Model Markowitz.

Sedangkan berdasarkan pengujian statistik sebagaimana dapat dilihat dari Tabel 5 dapat diketahui bahwa nilai t-hitung sebesar 0,110 dengan sig (2-tailed) sebesar 0,916 . Oleh karena nilai sig (2-tailed) $>$ dari 0,05, maka hipotesis Ho diterima dan $\mathrm{Ha}$ ditolak. Artinya rata-rata indikator kinerja portofolio ukuran Sharpe (Sharpe Measure) yang dibentuk menggunakan Model Markowitz dengan Model Indeks Tunggal tidak berbeda nyata. Penelitian ini membuktikan bahwa penilaian kinerja portofolio berdasarkan indikator kinerja portofolio ukuran Sharpe yang dibentuk dari portofolio optimal Model Markowitz tidak berbeda nyata bila dibandingkan dengan kinerja dari portofolio optimal Model Indeks Tunggal.
Volume 8 Nomor 3 (September - Desember) 2021

Dari Lampiran 6 dapat dilihat bahwa dengan melakukan simulasi investasi rill berdasarkan pembentukan portofolio yang dihasilkan oleh Model Markowitz dan model Indeks Tunggal menunjukkan kinerja yang pluaktuatif. Pada periode 2016 kinerja investasi yang dihasilkan Model Indeks Tunggal lebih tinggi dengan sangat signifikan dibanding kinerja investasi yang dihasilkan oleh Model Markowitz. Periode 2017 menunjukkan kinerja investasi yang dihasilkan oleh Model Indeks Tunggal lebih tinggi secara signifikan dibanding kinerja investasi yang dihasilkan oleh Model Markowitz. Tetapi pada periode 2018 kinerja investasi yang dihasilkan oleh Model Markowitz lebih tinggi secara signifikan dibanding kinerja Model Indeks Tunggal. Demikian juga pada periode 2019 kinerja investasi Model Markowitz lebih tinggi dibanding kinerja investasi Model Indeks Tunggal. Maka dapat disimpulkan secara faktual kinerja investasi berdasarkan pembentukan portofolio optimal Model Indeks Tunggal lebih tinggi dari kinerja investasi berdasarkan pembentukan portofolio optimal Model Markowitz.

\section{KESIMPULAN DAN SARAN}

\section{Kesimpulan}

Dari hasil analisis dan pembahasan, maka dapat ditarik beberapa kesimpulan sebagai berikut:

1) Komposisi saham dan proporsi dana yang terbentuk optimal terdapat perbedaan antara Model Markowitz dan Model Indeks Tunggal. Penggunaan Model Markowitz menghasilkan 
komposisi saham dan proporsi dana yang berbeda dibanding dengan penggunaan Model Indeks Tunggal meskipun bersumber dari kandidat saham yang masuk ke dalam portofolio yang sama.

2) Hasil analisis terhadap simulasi riil pembentukan kinerja portofolio optimal menunjukkan bahwa tingkat imbal hasil portofolio optimal menggunakan Model Markowitz lebih tinggi dibandingkan dengan tingkat imbal hasil portofolio optimal menggunakan Model Indeks Tunggal. Di sisi lain, tingkat risiko portofolio optimal menggunakan Model Markowitz lebih tinggi dibandingkan dengan tingkat risiko portofolio optimal menggunakan Model Indeks Tunggal.

3) Tingkat imbal hasil dan risiko portofolio optimal yang dibentuk menggunakan Model Markowitz dan Model Indeks Tunggal tidak berbeda nyata secara statistik.

4) Kinerja portofolio optimal yang dibentuk menggunakan Model Markowitz dan Model Indeks Tunggal yang diukur menggunakan indikator ukuran Sharpe (Sharpe Measure) secara investasi riil menunjukkan kinerja portofolio optimal Model Indeks Tunggal lebih tinggi dibanding kinerja portofolio Model Markowitz akan tetapi berdasarkan hasil pengujian statistik relatif tidak berbeda nyata.

\section{Saran}

Berdasarkan kesimpulan di atas terdapat beberapa saran yang perlu dipertimbangkan sebagai berikut:

1) Investor sebaiknya menggunakan Model Indeks Tunggal dalam menentukan portofolio Optimal dalam melakukan investasinya di pasar modal. Model Indeks Tunggal mengestimasi risiko yang lebih rendah dibanding Model Markowitz. Kemudian Model Indeks Tunggal memperhitungkan perubahan pasar dan melakukan perhitungannya lebih sederhana.

2) Penelitian selanjutnya, diharapkan dapat memberikan masukan bagi penelitian selanjutnya yang terkait dengan pembentukan portofolio dan penilaian kinerja portofolio. Dalam mengatasi keterbatasn penelitian ini, penulis merekomendasikan dua perbaikan yaitu:

a) Memasukkan saham yang masuk Top 20 Gainers Stocks dan saham saham yang sedang mengalami pertumbuhan dan bernilai di luar kelompok saham Indeks LQ-45 untuk digabungkan sebagai populasi dan sampel penelitian.

b) Data harga saham yang digunakan adalah harga penutupan (closing price) harian.

\section{DAFTAR PUSTAKA}

Bodie, Zvi; Alex Kane, Alan J. Marcus, dan Ravi Jain. (2014). Investments. Asia Global Edition. New York: McGrawHill Global Education Holding, LLC.

Elton, E. J.; Martin J. Grubber, Stephen J. Brown dan William N. Goetzmann (2014). Modern Portfolio Theory and Investment Analysis. Ninth Edition. John Wiley \& Sons, Inc.

Fama, E. F. (1970). Efficient Capital Markets: A Review of Theory and Empirical Work. Journal of Finance 25. Hal. 383-417. 
Printed ISSN : $2406-7415$

Electronic ISSN : $2655-9919$

Hartono, Jogiyanto. 2013. Teori Portofolio dan Analisis Investasi, Edisi Kedelapan. Yogyakarta: BPFE.

Hartono, Jogiyanto. 2014. Teori dan Praktik Portofolio dengan Excel. Jakarta: Salemba Empat.

Husnan, Suad. (2015). Dasar-Dasar Teori Portofolio \& Analisis Sekuritas. Edisi Kelima. Yogyakarta: UPP STIM YKPN.

Jones, Charles P. (2010). Investments Principles and Concepts. Eleventh Edition. John Wiley \& Sons (Asia) Pte. Ltd.

Markowitz, Harry M. (1952). Portofolio Selection. Journal of Finance.

Reilly, Frank K dan Keith C. Brown. (2012). Analysis of Investments \& Management of Portfolio. Tenth Edition. South-Western: Cengage Learning.

Tandelilin, Eduardus. (2010). Portofolio dan Investasi. Edisi Pertama. Yogyakarta: Kanisius.

\section{LAMPIRAN}

Lampiran 1: Komposisi Saham dan Proporsi Dana

\begin{tabular}{|c|c|c|r|r|r|r|r|r|r|}
\hline \multirow{2}{*}{ No. } & Kode & \multicolumn{2}{|c|}{2014} & \multicolumn{2}{|c|}{2015} & \multicolumn{2}{|c|}{2016} & \multicolumn{2}{|c|}{2017} \\
\hline & Emiten & Marko & SIM & Marko & SIM & Marko & SIM & Marko & SIM \\
\hline 1 & AALI & $22.14 \%$ & & & & & & & $2.50 \%$ \\
\hline 2 & AKRA & & & & & & $76.40 \%$ & & \\
\hline 3 & ADRO & & & & & & & & $23.01 \%$ \\
\hline 4 & ASII & & & & & & & & $5.64 \%$ \\
\hline 5 & ASRI & & & & & & & & $2.19 \%$ \\
\hline 6 & BBCA & & & & $5.99 \%$ & $40.69 \%$ & & $43.48 \%$ & $5.00 \%$ \\
\hline 7 & BBNI & & & $19.77 \%$ & $14.19 \%$ & & & & $3.59 \%$ \\
\hline 8 & BBRI & & & $1.03 \%$ & $9.24 \%$ & $10.03 \%$ & & & \\
\hline 9 & BBTN & & & & & & $13.69 \%$ & & $4.27 \%$ \\
\hline 10 & BMRI & & & $0.04 \%$ & $11.00 \%$ & $3.43 \%$ & & & $3.89 \%$ \\
\hline 11 & BSDE & & & $12.14 \%$ & $4.69 \%$ & $4.46 \%$ & & & $1.69 \%$ \\
\hline 12 & CPIN & & & & & & $1.07 \%$ & & \\
\hline 13 & GGRM & & & $3.72 \%$ & $3.40 \%$ & & $3.35 \%$ & & \\
\hline 14 & ICBP & & $38.65 \%$ & $2.24 \%$ & $3.47 \%$ & $41.38 \%$ & $2.71 \%$ & $6.44 \%$ & $0.71 \%$ \\
\hline 15 & INCO & & & & $2.04 \%$ & & & & \\
\hline 16 & INDF & & & & & & & & $3.58 \%$ \\
\hline 17 & INTP & & & & & & & & \\
\hline 18 & JSMR & & & & $8.85 \%$ & & & & $2.75 \%$ \\
\hline 19 & KLBF & & & $39.42 \%$ & $14.79 \%$ & & & $13.34 \%$ & \\
\hline 20 & LSIP & & & & & & & & \\
\hline 21 & LPKR & & & & $1.22 \%$ & & & & \\
\hline 22 & MNCN & & & $7.89 \%$ & & & & & \\
\hline 23 & PGAS & $9.11 \%$ & & & & & & & $1.63 \%$ \\
\hline 24 & PTBA & & & $13.77 \%$ & $2.18 \%$ & & & $18.64 \%$ & $12.31 \%$ \\
\hline 25 & PWON & & & & $2.96 \%$ & & & & \\
\hline 26 & SMGR & & & & & & & \\
\hline 27 & TLKM & $29.07 \%$ & & & $3.12 \%$ & & $2.79 \%$ & $7.93 \%$ & $6.03 \%$ \\
\hline 28 & UNVR & $14.24 \%$ & $50.24 \%$ & & $8.62 \%$ & & & & $9.95 \%$ \\
\hline 29 & UNTR & $20.11 \%$ & & & & & & $3.16 \%$ & $9.82 \%$ \\
\hline 30 & WIKA & $5.33 \%$ & $11.12 \%$ & & $4.23 \%$ & & & $7.01 \%$ & $1.44 \%$ \\
\hline \multicolumn{2}{|c|}{ Total } & $100.00 \%$ & $100.00 \%$ & $100.00 \%$ & $100.00 \%$ & $100.00 \%$ & $100.00 \%$ & $100.00 \%$ & $100.00 \%$ \\
\hline
\end{tabular}

Lampiran 2. Hasil Komputasi Portofolio Optimal Model Markowitz

\begin{tabular}{|c|c|c|c|c|c|c|c|c|}
\hline \multirow{2}{*}{ Keterangan } & \multicolumn{2}{|c|}{2016} & \multicolumn{2}{|c|}{2017} & \multicolumn{2}{|c|}{2018} & \multicolumn{2}{|c|}{2019} \\
\hline & Bulanan & Tahunan & Bulanan & Tahunan & Bulanan & Tahunan & Bulanan & Tahunan \\
\hline $\mathrm{E}(\mathrm{Rp})$ & $1,23 \%$ & $14,80 \%$ & $2,37 \%$ & $28,39 \%$ & $2,00 \%$ & $23,94 \%$ & $1,54 \%$ & $18,49 \%$ \\
\hline Var_P & $0,05 \%$ & $0,16 \%$ & $0,01 \%$ & $0,03 \%$ & $0,07 \%$ & $0,26 \%$ & $0,08 \%$ & $0,28 \%$ \\
\hline Std Dev_P & $2,12 \%$ & $3,95 \%$ & $0,96 \%$ & $1,78 \%$ & $2,72 \%$ & $5,07 \%$ & $2,86 \%$ & $5,32 \%$ \\
\hline Jumlah Saham & \multicolumn{2}{|c|}{6 Saham } & \multicolumn{2}{|l|}{$9 \mathrm{~S}$} & \multicolumn{2}{|l|}{$5 \mathrm{Sa}$} & \multicolumn{2}{|c|}{7 Saham } \\
\hline
\end{tabular}

Lampiran 3. Hasil Komputasi Portofolio Optimal Model Indeks Tunggal

\begin{tabular}{|c|c|c|c|c|c|c|c|c|}
\hline \multirow{2}{*}{ Keterangan } & \multicolumn{2}{|c|}{2016} & \multicolumn{2}{|c|}{2017} & \multicolumn{2}{|c|}{2018} & \multicolumn{2}{|c|}{2019} \\
\hline & Bulanan & Tahunan & Bulanan & Tahunan & Bulanan & Tahunan & Bulanan & Tahunan \\
\hline $\mathrm{E}(\mathrm{Rp})$ & $1,19 \%$ & $14,24 \%$ & $2,33 \%$ & $27,96 \%$ & $2,68 \%$ & $32,18 \%$ & $1,15 \%$ & $13,82 \%$ \\
\hline Var_P & $0,02 \%$ & $0,07 \%$ & $0,00 \%$ & $0,00 \%$ & $0,03 \%$ & $0,11 \%$ & $0,00 \%$ & $0,01 \%$ \\
\hline Std Dev_P & $1,45 \%$ & $2,71 \%$ & $0,25 \%$ & $0,46 \%$ & $1,75 \%$ & $6,05 \%$ & $0,57 \%$ & $1,97 \%$ \\
\hline Jumlah Saham & \multicolumn{2}{|c|}{3 Saham } & \multicolumn{2}{|c|}{16 Saham } & \multicolumn{2}{|c|}{6 Saham } & \multicolumn{2}{|c|}{18 Saham } \\
\hline
\end{tabular}

Lampiran 4. Perbandingan Imbal Hasil dan Risiko Portofolio Optimal

\begin{tabular}{|l|c|c|c|c|c|c|c|c|}
\hline \multirow{2}{*}{ Keterangan } & \multicolumn{2}{|c|}{2016} & \multicolumn{2}{|c|}{$\mathbf{2 0 1 7}$} & \multicolumn{2}{c|}{$\mathbf{2 0 1 8}$} & \multicolumn{2}{c|}{$\mathbf{2 0 1 9}$} \\
\cline { 2 - 8 } & MAR & MIT & MAR & MIT & MAR & MIT & MAR & MIT \\
\hline E(Rp) & $14,80 \%$ & $14,24 \%$ & $28,39 \%$ & $27,96 \%$ & $23,94 \%$ & $32,18 \%$ & $18,49 \%$ & $13,82 \%$ \\
\hline Var_P & $0,16 \%$ & $0,07 \%$ & $0,03 \%$ & $0,00 \%$ & $0,26 \%$ & $0,11 \%$ & $0,28 \%$ & $0,01 \%$ \\
\hline Std Dep_P & $3,95 \%$ & $5,04 \%$ & $1,78 \%$ & $0,46 \%$ & $9,44 \%$ & $6,05 \%$ & $5,32 \%$ & $1,97 \%$ \\
\hline
\end{tabular}


Printed ISSN : $2406-7415$

Electronic ISSN : $2655-9919$

DOI: http://dx.doi.org/10.35137/jabk.v8i3.598

JURNAL AKUNTANSI DAN BISNIS KRISNADWIPAYANA

Volume 8 Nomor 3 (September - Desember) 2021

Lampiran 5. Rekapitulasi Indikator Kinerja

Portofolio

\begin{tabular}{|c|c|c|c|c|r|r|}
\hline Periode & Model & $\mathbf{E}(\mathbf{R p})$ & $\boldsymbol{\sigma}_{\mathbf{p}}$ & $\mathbf{R}_{\mathbf{f}}$ & $\mathbf{C V}$ & Sharpe \\
\hline \multirow{2}{*}{2016} & MAR & $1,23 \%$ & $2,12 \%$ & \multirow{2}{*}{$6,75 \%$} & 1,72 & 0,316 \\
\cline { 2 - 7 } & SIM & $1,19 \%$ & $1,45 \%$ & & 1,22 & 0,434 \\
\hline \multirow{2}{*}{2017} & MAR & $2,37 \%$ & $0,96 \%$ & \multirow{2}{*}{$6,75 \%$} & 0,41 & 1,885 \\
\cline { 2 - 7 } & SIM & $2,33 \%$ & $0,25 \%$ & & 0,11 & 7,08 \\
\hline \multirow{2}{*}{2018} & MAR & $2,00 \%$ & $2,72 \%$ & \multirow{2}{*}{$5,75 \%$} & 1,36 & 0,559 \\
\cline { 2 - 7 } & SIM & $2,68 \%$ & $1,75 \%$ & & 0,65 & 1,257 \\
\hline \multirow{2}{*}{2019} & MAR & $1,54 \%$ & $2,86 \%$ & \multirow{2}{*}{$4,75 \%$} & 1,86 & 0,399 \\
\cline { 2 - 6 } & SIM & $1,15 \%$ & $0,57 \%$ & 0,5 & 1,316 \\
\hline
\end{tabular}

Lampiran 6. Perhitungan Kinerja Portofolio Aktual

\begin{tabular}{|c|c|c|r|r|r|}
\hline \multirow{2}{*}{ Periode } & \multirow{2}{*}{ Model } & \multicolumn{2}{|c|}{ Nilai Investasi } & \multicolumn{1}{c|}{ Imbal Hasil Investasi } \\
\cline { 3 - 6 } & & Awal & \multicolumn{1}{c|}{ Akhir } & \multicolumn{1}{c|}{ Nominal } & \multicolumn{1}{c|}{$\%$} \\
\hline \multirow{2}{*}{2016} & MAR & 999.747 .000 & 1.110 .601 .000 & 110.854 .000 & $11,09 \%$ \\
\cline { 2 - 6 } & MIT & 997.572 .500 & 1.321 .885 .500 & 324.313 .000 & $32,51 \%$ \\
\hline \multirow{2}{*}{2017} & MAR & 999.966 .000 & 686.980 .500 & -312.985 .500 & $-31,30 \%$ \\
\cline { 2 - 6 } & MIT & 996.971 .500 & 820.764 .200 & -176.207 .300 & $-17,67 \%$ \\
\hline \multirow{2}{*}{2018} & MAR & 999.709 .000 & 1.096 .977 .000 & 97.268 .000 & $9,73 \%$ \\
\cline { 2 - 6 } & MIT & 997.886 .000 & 883.219 .500 & -114.666 .500 & $-11,49 \%$ \\
\hline \multirow{2}{*}{2019} & MAR & 999.165 .000 & 1.097 .333 .500 & 98.168 .500 & $9,83 \%$ \\
\cline { 2 - 6 } & MIT & 999.137 .900 & 1.074 .840 .100 & 75.702 .200 & $7,58 \%$ \\
\hline
\end{tabular}

